\title{
The Influence of Clamshell on Mechanical Properties of Non- Structure Concrete as Artificial Reef
}

\author{
Rudhy Akhwady ${ }^{1}$, Ridho Bayuaji ${ }^{2, *}$ \\ ${ }^{1}$ Ministry of Marine Affairs and Fisheries Indonesia \\ ${ }^{2}$ Civil Infrastructure Engineering, Institut Teknologi Sepuluh Nopember \\ Jl Menur 127 (Surabaya, Indonesia) \\ *Corresponding author's email: bayuaji [AT] ce.its.ac.id
}

\begin{abstract}
Clamshell waste had higher chemical content of Calcium Carbonate (CaCO3) than the limestone, egg shells, ceramic, or other materials. These physical properties gave the potential for material substitution as coarse aggregate in concrete artificial reefs. In addition, the utilization of leather waste in concrete structures could function as taxis for fish in the vicinity. This study utilized two types of coarse aggregate (filler) which were crushed stone and/or clamshell waste of the blood clamshells and kurkur clamshells. The test was to identify the mechanical properties of concrete artificial reef namely: Hammer test (ASTM C805), abrasion test (ASTM C779), the pressure test (SNI 03-1974-1990), split tensile test (ASTM C496 / C496M-11), Ultrasonic Pulse Velocity (UPV) test (ASTM C597-16), Porosity test (C642-13), permeability test (SN 505 252/1). The Concrete mixing is conducted according to SNI 03-2834-2000 standard and quality standard of solid concrete brick (SNI 03-0349-1989). Before the test, the concrete soaked in fresh water and sea water and left in the open air until 28 days. The results showed that the use of clamshell waste as filler had potential as a concrete compressive strength of non-structure approaches to the quality of solid concrete brick, as artificial reef material.
\end{abstract}

Keywords - non-structure concrete, artificial reefs, clamshell waste, mechanical properties

\section{INTRODUCTION}

The use of local materials to support the infrastructure needs of the sea needed to be examined to indicate that local material in Indonesia had the potential to be used as building materials and structural materials, as conducted by the previous research [1-11].

This research focused on the waste shells on the coast of Surabaya in 2016 which received the attention of the national mass media, the problems of waste shells [12] was due to its large numbers of around 1 ton per day and polluted the coasts of Bulak Kenjeran as one of the developing tourism area in Surabaya. The waste seashells on the coast of Bulak Surabaya which was large enough and spread out along the coast to be considered disturbing the scenery and surroundings. The shells in previous studies [13-15] had the chemical content of calcium carbonate (CaCO3) in higher levels than the limestone, egg shells, ceramic, or other materials. The harder the shell, the higher the content of calcium carbonate $(\mathrm{CaCO} 3)$ in it. This physical properties was a good opportunity to substitute the coarse aggregate in concrete, so this research was given the term Shell Waste Concrete (BLK) non structural concrete for artificial reef.

Sea scallops (Anadara grandis) [16] was one of the many types of shellfish found in Indonesian waters. These types of shellfish were widely consumed because of its high contain in protein. The content of the waste shells after investigation contains many chemical compounds that were pozzolan was lime $(\mathrm{CaO})$ at $66.70 \%$, alumina, and silica compounds [17]. The element content of lime $(\mathrm{CaO})$ was needed as the primary raw material or to substitute cement manufacturing or could be used as mixture in paving block, brick or buiss concrete. Several studies have linked the use of shells including for the cement composition was[18-20]. While the use of shells for additional adobe mix made by Kusuma et al [21]. The shells that were used in this study were the Kur-kur species of mussels and blood clams. These were the type commonly found at the research sites.

Seashells and concrete was the material commonly used for artificial reefs. In practice, the shells used as artificial reefs for shellfish growing living media. Concrete was one of the ingredients that have been proven very well be used as 
an artificial reef material, because it can be integrated with the environment [22]. In this research, waste shells were used for concrete mixture and investigated whether there were any additional effects of clamshell on the concrete mix to increased interest nature of fish on the artificial reef.

Artificial reefs were structures or frameworks that deliberately placed into the sea as a shelter and habitat for marine organisms, such as tacks for coral larvae and FADs, or as a coastal protection. It was also an alternative strategy of rehabilitation of coral reef resources and its habitat, with the procurement of new habitats in the marine space and the provision of the substrate layer to the feeding area for fish, crustaceans and mollusks [22]. The purpose of this paper was to provide an overview of waste shells that could be used as an alternative material for the manufacture of artificial reefs

\section{RESEARCH METHOD}

The research was done in Material and Building Structure Laboratory, Department of Civil Infrastructure Engineering, Institut Teknologi Sepuluh Nopember. With testing scenario as follows:

1. Coarse Aggregate Concrete (Normal)

2. Coarse Aggregate Concrete Kur-Kur Shells

$: \mathrm{CN}$
$: \mathrm{C} 101$
$: \mathrm{C} 201$
$: \mathrm{C} 301$
$: \mathrm{C} 102$
$: \mathrm{C} 202$
$: \mathrm{C} 302$

3. Coarse Aggregate Concrete Blood Shells

4. Coarse Aggregate Concrete Mixed Shells

5. Coarse Aggregate Concrete Kur-Kur Shells and Broken Stone : C102

6. Coarse Aggregate Concrete Blood Shells and Broken Stone : C202

7. Coarse Aggregate Concrete Mixed Shells and Broken Stone : C302

Shells capturing in Bulak Kenjeran coast as one of the development of tourism in Surabaya. The steps in research includes examination of test materials and mix design that aimed to produce the composition of the concrete mix in the right proportions. Then proceed to the manufacturing phase of the test specimen preparation in the form of mold, concrete mixing and stirring, printing specimen, care for 28 days, treatment (curing) concrete carried out with air, fresh water and sea water. Then the testing was done on cylindrical specimen material totaling 235 units with several kinds of tests as follows:

Concrete Pressure Strength Test Method [23], Ultrasonic Pulse Velocity Test (ASTM C597-16), Hammer Test [24], Abration Test (ASTM C779/C779M-12), Tensile Split Test (ASTM C496/C496M-11), Concrete Axis Test (C642-13), Concrete Permeability Test (SN 505 252/1), Standard Concrete Mixing [25], Quality Concrete Brick Ductile [26].

\section{RESULTS AND DISCUSSION}

Material test aimed to determine the physical characteristics of each material which conceived the concrete. The test results could be seen in Table 1. Mixed design aimed to produce a composition of concrete mix in the right proportions. The test results were shown in Table 2. After testing the materials and mix design were done, the result would be a reference in the manufacture of test specimens.

Table 1: Material Test Results

\begin{tabular}{llccccc}
\hline \multirow{2}{*}{ No } & Type of material test & Sand & $\begin{array}{c}\text { Crushed } \\
\text { stone }\end{array}$ & $\begin{array}{c}\text { Kurkur } \\
\text { Shell }\end{array}$ & $\begin{array}{c}\text { Blood } \\
\text { shell }\end{array}$ & Mix \\
\hline 1 & Sieve analysis (zone) & Zone 3 & Max 40 & Max 40 & Max 40 & Max 40 \\
\hline 2 & $\begin{array}{l}\text { Max Aggregate } \\
\text { Measurement(mm) }\end{array}$ & 2.38 & 38.1 & 19.05 & 50.80 & 19.05 \\
\hline 3 & Density (T/m3) & 2.69 & 2.66 & 3.37 & 2.25 & 2.32 \\
\hline 4 & Catchment (\%) & 2.48 & 6.69 & 3.91 & 5.14 & 4.09 \\
\hline 5 & Humidity (\%) & 7.78 & 4.67 & 0.35 & 0.62 & 1.02 \\
\hline 6 & Volume (T/m3) & 1.42 & 1.26 & 0.53 & 0.42 & 0.54 \\
\hline 7 & Sludge Content (\%) & 3.8 & 2.51 & 3.41 & 1.04 & 1.97 \\
\hline 8 & Organic Content (\%) & Color 2 & & - & 76.19 & 63.33 \\
\hline 9 & Impact Factor (\%) & & 15.39 & 58.06 & 25.6 & 26.9 \\
\hline 10 & Abrasion (\%) & & 37.18 & 26.38 & - \\
\hline
\end{tabular}


Table 1: Material Test Results

Table 2: Results Mixed Designs by weight measurement in the volume of $1 \mathrm{~m}^{3}$ Concrete

\begin{tabular}{|c|c|c|c|c|c|c|c|}
\hline Code & $\begin{array}{c}\text { Cement } \\
\quad(\mathrm{Kg})\end{array}$ & $\begin{array}{l}\text { Sand } \\
(K g)\end{array}$ & $\begin{array}{c}\text { Crushed } \\
\text { stone }(\mathrm{Kg})\end{array}$ & $\begin{array}{c}\text { Kurkur } \\
\text { clamshell } \\
(\text { Kg })\end{array}$ & $\begin{array}{c}\text { Blood } \\
\text { clamshell } \\
(\mathrm{Kg})\end{array}$ & $\begin{array}{c}\text { Mixed } \\
\text { Clamshell } \\
(\mathrm{Kg})\end{array}$ & $\begin{array}{l}\text { Water } \\
\text { (Liter) }\end{array}$ \\
\hline $\mathrm{CN}$ & 315.4 & 751.8 & 1127.8 & - & - & - & 205 \\
\hline C101 & 315.4 & 1503.7 & - & 375.9 & - & - & 205 \\
\hline $\mathrm{C} 201$ & 315.4 & 1503.7 & - & - & 375.9 & - & 205 \\
\hline C301 & 315.4 & 1503.7 & - & & - & 375.9 & 205 \\
\hline $\mathrm{C} 102$ & 315.4 & 1503.7 & 281.9 & 281.9 & - & - & 205 \\
\hline C202 & 315.4 & 1503.7 & 281.9 & - & 281.9 & - & 205 \\
\hline $\mathrm{C} 302$ & 315.4 & 1503.7 & 281.9 & - & - & 281.9 & 205 \\
\hline
\end{tabular}

Hammer Test was a type of testing without damaging the concrete (non-destructive) for the purpose of estimating the quality of concrete based on the reflection of tool hammer against the concrete at 28 days. The test results were shown in Table 3.

Table 3: Hammer Test Results

\begin{tabular}{|c|c|c|c|c|c|c|c|c|}
\hline \multirow{3}{*}{ Code } & \multicolumn{8}{|c|}{ Average result of Hammer Test } \\
\hline & \multicolumn{2}{|c|}{ Air Curing } & \multicolumn{3}{|c|}{ Water Curing } & \multicolumn{3}{|c|}{$\begin{array}{l}\text { Kenjeran Sea } \\
\text { Water Curing }\end{array}$} \\
\hline & Q & $\mathrm{s}(\mathrm{MPa})$ & Q & $\mathrm{s}$ & (MPa) & $\mathrm{Q}$ & $\mathrm{s}$ & $(\mathrm{MPa})$ \\
\hline $\mathrm{CN}$ & 35.5 & 14.9 & 28.7 & & 9.7 & 31.2 & & 11.2 \\
\hline C101 & 26.6 & 8.5 & 20.9 & & 5.9 & 22.0 & & 6.1 \\
\hline C201 & 23.0 & 6.8 & 16.5 & & 4.5 & 16.1 & & 4.3 \\
\hline C301 & 24.3 & 7.3 & 22.8 & & 6.7 & 20.4 & & 5.6 \\
\hline C102 & 30.2 & 10.7 & 26.4 & & 8.4 & 21.1 & & 6.3 \\
\hline $\mathrm{C} 202$ & 26.2 & 8.2 & 21.2 & & 6.0 & 16.6 & & 4.5 \\
\hline C302 & 29.1 & 9.9 & 28.4 & & 9.4 & 20.3 & & 5.5 \\
\hline
\end{tabular}

Pressure test was a type of testing to destruct the most important concrete in order to determine the compressive strength or quality of concrete at the age of 3 days and 28 days. The test results were shown in Table 4 and Table 5 .

Table 4: Results of Concrete Compressive Strength at age of 3 days

\begin{tabular}{cc}
\hline & $\begin{array}{c}\text { Average Compressive } \\
\text { Code }\end{array}$ \\
& Strength Test Results, \\
& Wcr $(\mathbf{M P a})$ \\
\hline CN & Water Curing \\
\hline C101 & 10.66 \\
\hline C201 & 3.69 \\
\hline C301 & 1.53 \\
\hline C102 & 3.49 \\
\hline C202 & 4.85 \\
\hline C302 & 2.61 \\
\hline
\end{tabular}


The result of the compressive strength of concrete was done at the age of 3 days and 28 days. Compressive strength at age of 3 days compared to the concrete at the age of 28 days had an increase and would increase more compared to the curing concrete in seawater. The strength of the mixture C102 appeared better than the other mixtures. However, it still could not match the normal concrete $(\mathrm{CN})$. The test results were shown in Table 5.

Table 5: Results of Concrete Compressive Strength at age of 28 days

\begin{tabular}{ccc}
\hline \multirow{2}{*}{ Code } & $\begin{array}{c}\text { Average Compressive Strength } \\
\text { Test Results, } \boldsymbol{f}_{\text {cr }}(\mathbf{M P a})\end{array}$ \\
\cline { 2 - 3 } & Water Curing & $\begin{array}{c}\text { Kenjeran } \\
\text { seawater } \\
\text { Curing }\end{array}$ \\
\hline $\mathrm{CN}$ & 8.95 & 16.07 \\
\hline $\mathrm{C} 101$ & 6.51 & 8.63 \\
\hline $\mathrm{C} 201$ & 4.02 & 3.80 \\
\hline $\mathrm{C} 301$ & 6.03 & 6.03 \\
\hline $\mathrm{C} 102$ & 7.64 & 9.00 \\
\hline $\mathrm{C} 202$ & 3.36 & 5.76 \\
\hline $\mathrm{C} 302$ & 7.21 & 8.47 \\
\hline
\end{tabular}

Table 6 shows the Ultrasonic Pulse Velocity (UPV) test results. It was a type of testing without damaging the concrete (Non-Destructive) for the purpose of estimating the quality of concrete based on the relationship UPV wave velocity through the medium of concrete at 28 days.

Table 6: Ultrasonic Pulse Velocitiy (UPV) Test Results

\begin{tabular}{lccc}
\hline Code & \multicolumn{2}{c}{ Average Results of UPV Test, $\mathbf{V}(\mathrm{Km} / \mathrm{sec})$} \\
& Air Curing & Water Curing & $\begin{array}{c}\text { Kenjeran sea } \\
\text { water Curing }\end{array}$ \\
\hline CN & 2.6 & 2.7 & 3.2 \\
\hline C101 & 2.0 & 2.7 & 2.8 \\
\hline C201 & 1.8 & 2.4 & 1.9 \\
\hline C301 & 2.2 & 2.4 & 2.8 \\
\hline C102 & 2.2 & 2.8 & 2.6 \\
\hline C202 & 2.2 & 2.3 & 2.6 \\
\hline C302 & 2.2 & 2.8 & 4.4 \\
\hline
\end{tabular}

The Abrasion test results (Table 7) was a type of destructive concrete testing in order to determine the amount of time loss and the size of the layer of concrete by the load erosion of the abrasion testing tool at 28 days. 
Table 7: The Abrasion Test Results

\begin{tabular}{|c|c|c|c|c|c|c|c|}
\hline \multirow{3}{*}{ Code } & \multicolumn{6}{|c|}{ The Abrasion Average Results } & \multirow{3}{*}{ Information } \\
\hline & \multicolumn{2}{|c|}{ Air Curing } & \multicolumn{2}{|c|}{ Water Curing } & \multicolumn{2}{|c|}{$\begin{array}{l}\text { Kenjeran sea } \\
\text { water Curing }\end{array}$} & \\
\hline & $\%$ & mm/minute & $\%$ & $\mathrm{~mm} /$ minute & $\%$ & $\begin{array}{c}\text { mm/minut } \\
\text { e }\end{array}$ & \\
\hline $\mathrm{CN}$ & 0.12 & 0.05 & 0.40 & 0.16 & 0.29 & 0.11 & \multirow{6}{*}{$\begin{array}{l}\text { Percent Unit }(\%) \text { denoted percent of } \\
\text { time loss, whereas in mm / min } \\
\text { indicated a reduction in the size of the } \\
\text { layer of concrete in unit of mm per } 1 \\
\text { minute abrasion testing. The smaller the } \\
\text { value of testing the concrete quality was } \\
\text { getting better, and vice versa. }\end{array}$} \\
\hline $\mathrm{C} 101$ & 0.78 & 0.30 & 0.82 & 0.33 & 0.84 & 0.34 & \\
\hline C201 & 0.91 & 0.34 & 1.41 & 0.57 & 1.21 & 0.50 & \\
\hline C301 & 0.45 & 0.17 & 0.74 & 0.31 & 0.66 & 0.27 & \\
\hline C102 & 0.26 & 0.10 & 0.98 & 0.39 & 0.86 & 0.36 & \\
\hline C202 & 0.78 & 0.29 & 1.34 & 0.53 & 0.56 & 0.23 & \\
\hline
\end{tabular}

Tensile Test was a type of destructive concrete testing in order to determine the tensile strength of concrete sides with cylinder-shaped test specimens according to ASTM standards at 28 days. The test results were shown in Table 8.

Table 8: Concrete Tensile Test Results

\begin{tabular}{lccc}
\hline \multirow{2}{*}{ Code } & \multicolumn{2}{c}{ Concrete Tensile Test Average Results, fct (MPa) } \\
\cline { 2 - 4 } & Air Curing & Water Curing & $\begin{array}{c}\text { Kenjeran sea water } \\
\text { Curing }\end{array}$ \\
\hline CN & 1.36 & 1.59 & 1.72 \\
\hline C101 & 0.90 & 0.98 & 1.06 \\
\hline C201 & 0.61 & 0.64 & 0.51 \\
\hline C301 & 0.97 & 0.93 & 1.03 \\
\hline C102 & 0.94 & 1.08 & 0.67 \\
\hline C202 & 0.77 & 0.64 & 1.21 \\
\hline C302 & 0.93 & 0.93 & \\
\hline
\end{tabular}

Porosity and permeability test results (Table 9 and Table 10) were a type of testing without damaging the concrete (Non-Destructive) in order to measure the durability of the concrete structure of the clamshells waste. This test showed the percentage of free space on concrete or porous levels which became the major factor in influencing the quality of concrete at 28 days.

Table 9: Porosity Test Results

\begin{tabular}{lc}
\hline \multirow{2}{*}{ Code } & Water Curing \\
\cline { 2 - 2 } & Average Porosity (\%) \\
\hline C301 & 21.31 \\
\hline C302 & 18.82 \\
\hline
\end{tabular}


Table 10: Permeability test results

\begin{tabular}{lcc}
\hline \multirow{3}{*}{ Code } & \multicolumn{3}{c}{ Curing Air Tawar } \\
\cline { 2 - 3 } & Coefficient Permeability Average Results , & Depth Penetration Vacuum, L \\
& $\mathbf{k T}(\mathbf{1 0 - 1 6} \mathbf{~ m 2})$ & $(\mathbf{m m})$ \\
\hline C301 & 35.90 & 170 \\
\hline C302 & 85.50 & 227 \\
\hline
\end{tabular}

In general, the test results showed that the thickness level of clamshells was lower than the shells split/gravel; therefore, it caused a decrease in the compressive strength of concrete pressure which significantly compared to normal one. The decrease was also caused by the shape and texture of a larger volume of gravel split while the thin shells (the hollow inside) in causing an increase need for sand and the reduction of concrete strength.

\section{CONCLUSION}

The results of the study, concrete mix design with clamshell waste as non-structure material for artificial reef was conducted. Otherwise, for gaining strength above that would require SK SNI could be done by adding portland cement on top of the mix design was acquired. Kurkur clamshell waste as concrete materials or a mixture of interchangeable clamshells used as artificial reefs was expected to have "fishy" concrete and could be fishing "chamotaxis" [27].

\section{ACKNOWLEDGEMENT}

The author thank to Ministry of Marine Affairs and Fisheries Indonesia and Ministry of Research, Technology and Higher Education of the Republic of Indonesia for funded this research.

\section{REFERENCES}

[1] R. Bayuaji, "Studi Literatur dan Prospek Penelitian Beton Porus Sebagai Material Struktur dan Bahan Bangunan " presented at the Seminar Nasional Aplikasi Teknologi Prasarana Wilayah 2011, Prodi Diploma Teknik Sipil FTSP ITS, 2011.

[2] M. Nuruddin, R. Bayuaji, M. Masilamani, and T. Biyanto, "Sidoarjo mud: A potential cement replacement material," Civil Engineering Dimension, vol. 12, pp. 18-22, 2010.

[3] R. Bayuaji, M. Sigit Darmawan, B. Wibowo, N. Ahmad Husin, S. Subekti, and J. J. Ekaputri, "The Influence of Chloride Environment on Compressive Strength of Geopolymer Concrete with Fly Ash Using Taguchi Approach," in Applied Mechanics and Materials, 2015, pp. 400-405.

[4] W. Supriadi, R. Bayuaji, R. Burhan, and H. Fansuri, "The Effect of Pb 2+ and Cd 2+ Addition to Mechanical Properties of Fly Ash Geopolymer Paste," in Materials Science Forum, 2016.

[5] H. Fansuri, A. Fatmawati, W. P. Utomo, W. Supriadi, and R. Bayuaji, "Cd 2+ and Cr 3+ Cation Immobilization by Using Geopolymer Based on PT. IPMOMI Fly Ash," in Materials Science Forum, 2016.

[6] R. Bayuaji, M. S. Darmawan, I. PUDJ, and N. A. HUSIN, "Characterization of Pozzolanicity Bromo‘s Volcanic Ash," in International Seminar on Applied Technology, Science, and Arts (3rd APTECS), Surabaya, 2011.

[7] R. Bayuaji, S. Darmawan, N. A. Husin, B. Wibowo, S. Subekti, J. J. Ekaputri, et al., "The Effect of High Temperature on Compression Strength of Geopolymer Paste," in MATEC Web of Conferences, 2017, p. 01020.

[8] R. Bayuaji, S. Darmawan, N. A. Husin, B. Wibowo, S. Subekti, M. M. A. B. Abdullah, et al., "The Effect of Corrosive Environment on Geopolymer Concrete Tensile Strength," in MATEC Web of Conferences, 2017, p. 01036.

[9] R. Bayuaji, M. S. Darmawan, B. Wibowo, N. Husin, and S. Subekti, "Utilization of High Calcium Content Fly Ash: Flexural Strength of Geopolymer Concrete Beams in Sea Water Environment," The Open Civil Engineering Journal, vol. 10, 2016.

[10] R. Bayuaji, R. Kurniawan, A. Yasin, H. A. Fatoni, and F. Lutfi, "The effect of fly ash and coconut fibre ash as cement replacement materials on cement paste strength," in IOP Conference Series: Materials Science and Engineering, 2016, p. 012014.

[11] M. S. Darmawan, R. Bayuaji, B. Wibowo, N. A. Husin, and S. Subekti, "The Effect of Chloride Environment on Mechanical Properties Geopolymer Binder with Fly Ash," in Key Engineering Materials, 2014, pp. 648-655. 
[12] S. Madival, R. Auras, S. P. Singh, and R. Narayan, "Assessment of the environmental profile of PLA, PET and PS clamshell containers using LCA methodology," Journal of Cleaner Production, vol. 17, pp. 1183-1194, 2009.

[13] J. F. Tavolaro, "A sediment budget study of clamshell dredging and ocean disposal activities in the New York bight," Environmental geology and water sciences, vol. 6, pp. 133-140, 1984.

[14] N. Asikin-Mijan, Y. Taufiq-Yap, and H. Lee, "Synthesis of clamshell derived Ca (OH) 2 nano-particles via simple surfactant-hydration treatment," Chemical Engineering Journal, vol. 262, pp. 1043-1051, 2015.

[15] P. Nair, B. Singh, S. Upadhyay, and Y. Sharma, "Synthesis of biodiesel from low FFA waste frying oil using calcium oxide derived from Mereterix mereterix as a heterogeneous catalyst," Journal of Cleaner Production, vol. 29, pp. 82-90, 2012.

[16] A. Miranda-Baeza, D. Voltolina, and B. Cordero-Esquivel, "Filtration and clearance rates of Anadara grandis juveniles (Pelecypoda, Arcidae) with different temperatures and suspended matter concentrations," Revista de biología tropical, vol. 54, pp. 787-792, 2006.

[17] S. M. Siregar, "Pemanfaatan kulit kerang dan resin epoksi terhadap karakteristik beton polimer," Medan: Tesis USU, 2009.

[18] N. A. Syafpoetri, M. Olivia, and L. Darmayanti, "Pemanfaatan Abu Kulit Kerang (Anadara grandis) Untuk Pembuatan Ekosemen," Penelitian Jurusan Teknik Sipil, FT Universitas Riau, Riau.< URL: http://repository. unri. ac. id/bitstream/123456789/2014/1/Nelvia\% 20Adi\% 20Syafpoetr i\% 200807135289. pdf, 2013.

[19] R. N. Nana Dyah Siswati, Riant Anggraini, "Pembuatan Ekosemen Dari Sampah Organik," Jurnal Teknik Kimia . vol. Vol.3 No.2, 2009.

[20] N. Susanti, "Pembuatan Ekosemen Dari Abu Sampah Dan Uji Aplikasinya Untuk Panel Beton," 2009.

[21] E. W. Kusuma, "Pemanfaatan Limbah Kulit Kerang Sebagai Bahan Campuran Pembuatan Paving Block," Teknik Lingkungan, Fakultas Teknis Sipil dan Perencanaan, Universitas Pembangunan Nasional Veteran Jatim Surabaya, 2012.

[22] DKP, Pedoman pengelolaan terumbu buatan dan transplantasi karang: Jakarta : Direktorat Jenderal Kelautan, Pesisir dan Pulau-pulau Kecil, Departemen Kelautan dan Perikanan Republik Indonesia, 2005.

[23] S. SNI, "SNI 03-1974-1990," Metode pengujian kuat tekan beton, 2013.

[24] ASTM-C805/C805M-13a, "Standard Test Method for Rebound Number of Hardened Concrete," ed. West Conshohocken: ASTM International, 2013.

[25] DPU, "Tata Cara Pembuatan Rencana Campuran Beton Normal dengan Standar SK SNI 03-2834-2000," Badan Standarisasi Nasional, 2000.

[26] P. Departemen, "SNI 03-0349-1989 Bata Beton untuk Pasangan Dinding," Balitbang, Jakarta, 1989.

[27] M. Nakamura, "Evolution of artificial fishing reef concepts in Japan," Bulletin of Marine Science, vol. 37, pp. 271-278, 1985. 